\title{
Effects of Human Impact on Miombo Woodland in Northern Malawi
}

\author{
Tina Vanadis Bundschuh, Rüdiger Wittig \& Karen Hahn
}

Summary: Miombo woodland is found throughout the Zambezian regional centre of endemism where most of the rural population make use of its wild plant species. This article presents the results of a study on the composition of the woody vegetation and its anthropogenous alteration in northern Malawi with particular respect to the impact caused by the collection of wild plants. The main vegetation type in this area is miombo woodland which is composed of 80 woody species. The collection of wild plants does not show an effect on the plant diversity but effects are visible in the decreasing number of tall trees.

Key words: vegetation, collection of wild plants

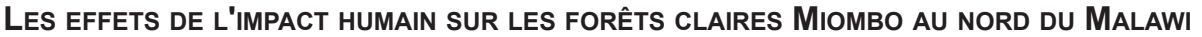

Résumé: Les forêts claires du type « miombo » prévalent dans le centre régional d'endémisme zambézien où la plupart de la population rurale utilise des plantes sauvages. Dans cet article les résultats des premières études botaniques dans cette région au nord de Malawi sont présentés. On a étudié et analysé la végétation en rapport avec les influences de son utilisation. La végétation principale de la région est la forêt claire du type " miombo ». Elle est composée par des 80 espèces de plantes ligneuses. Tandis qu'un effet sur la prévalence des arbres peut être observé, la composition floristique n'est pas altéré par l'utilisation des plantes sauvages.

Mots clés: végétation, utilisation, forêt claire

\section{Anthropogene Vegetationsveränderungen der Miombo-Savannen in NordmalaWı}

Zusammenfassung: Miombo Woodland ist die häufigste Vegetationsformation in der Sambesischen Florenregion, wo ein Großteil der Bevölkerung Wildpflanzen zu diversen Zwecken nutzt. In diesem Artikel werden die Ergebnisse einer in NordMalawi durchgeführten Untersuchung zur Zusammensetzung der Gehölzvegetation und deren anthropogenen Beeinflussungen vorgestellt. Die Hauptvegetationsformation der Region ist Miombo Woodland, das sich im Untersuchungsgebiet aus 80 Gehölzarten zusammensetzt. Die Artenzusammensetzung ist nicht durch die Nutzung der Wildpflanzen verändert, jedoch sind Einflüsse auf das Vorkommen von hohen Bäumen ersichtlich.

Schlagworte: Vegetation, Wildpflanzennutzung

\section{INTRODUCTION}

White (1983) describes the vegetation of Malawi as wet miombo woodland. The name miombo derived from the local name "muombo" (plural "miombo") for some Brachystegia species in the Zambezian regional centre of endemism (SMith \& AlLen 2004). Miombo woodland is dominated by the genera Julbernardia, Isoberlinia or Brachystegia and differs in its species composition from region to region.

Today, $61 \%$ of the country of Malawi is covered by farmland, $27 \%$ by miombo woodland (MACMILLAN 2005). Deforestation continues at a rate of $2.8-3.4 \%$. In Malawi, $85 \%$ of the population live in rural areas (HALle \& Burgess 2006). The energy demand is covered by the use of wood fuel or charcoal in $93 \%$ of the rural households.

Due to these facts, a general impression of a "fuel wood crisis" arose in the regions of dry tropical woodlands (HALLE \& BuRgess 2006). However, various studies showed that this impression was not verifiable in general but a sustainable use of woody resources could be possible if the consumption does not exceed a certain quantity (Аввот \& Homewood 1999, BANDA et al. 2006, DeweEs 1989, Foley 2001). The importance of woodland for the local population and the use of miombo species remains a subject of research and management issues (DEWEEs et al. 2010).
In northern Malawi, where miombo woodlands still occur, collection of wild plants is widespread and woodland is an important source for fuel wood, timbers, fruits and herbal medicines. First surveys about the most important woody species and their use in the area of Karonga and its surroundings indicate a high demand for harvesting of wild plant species (KAUNDA 2007). Thus, it is of specific interest to evaluate the effects of woody plant harvesting on the species composition of miombo woodlands. As basic information on miombo woodland, vegetation is lacking for northern Malawi. Therefore, the study was aimed as a first step at inventorying and documenting miombo woodland species composition.

Karonga and its surroundings are subject of international (geological/ paleontological) research since the 1980s, which advanced considerably when hominid fossils were found near Karonga in 1991 (SCHRENK et al. 1993). A museum was built at Karonga (Cultural and Museum Centre Karonga/ CMCK) and the excavation camp (Malema Camp) was turned into a research camp. 


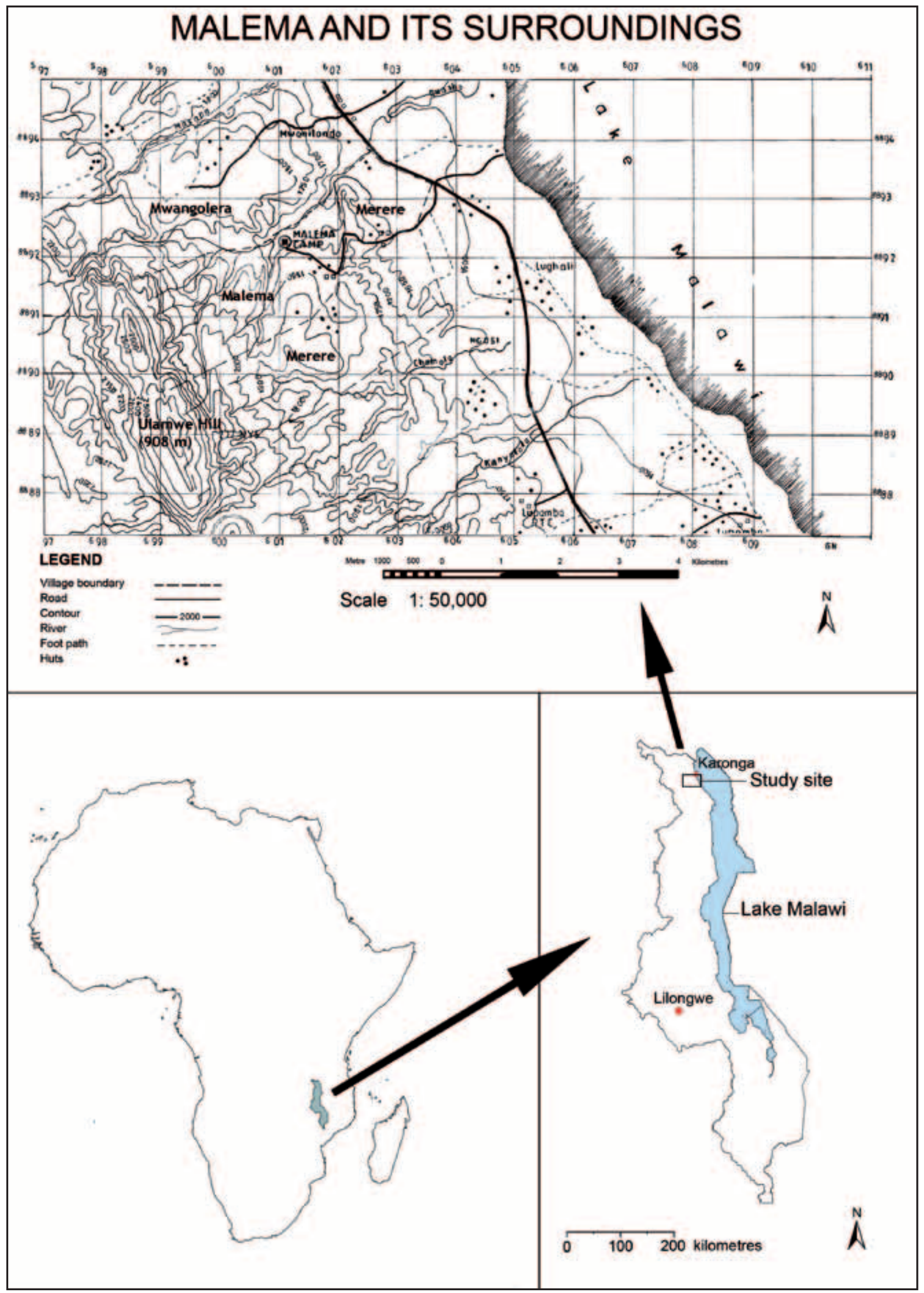

Fig. 1: The location of the study site in Malawi | La position du terrain d'étude en Malawi | Lage des Untersuchungsgebiets in Malawi 


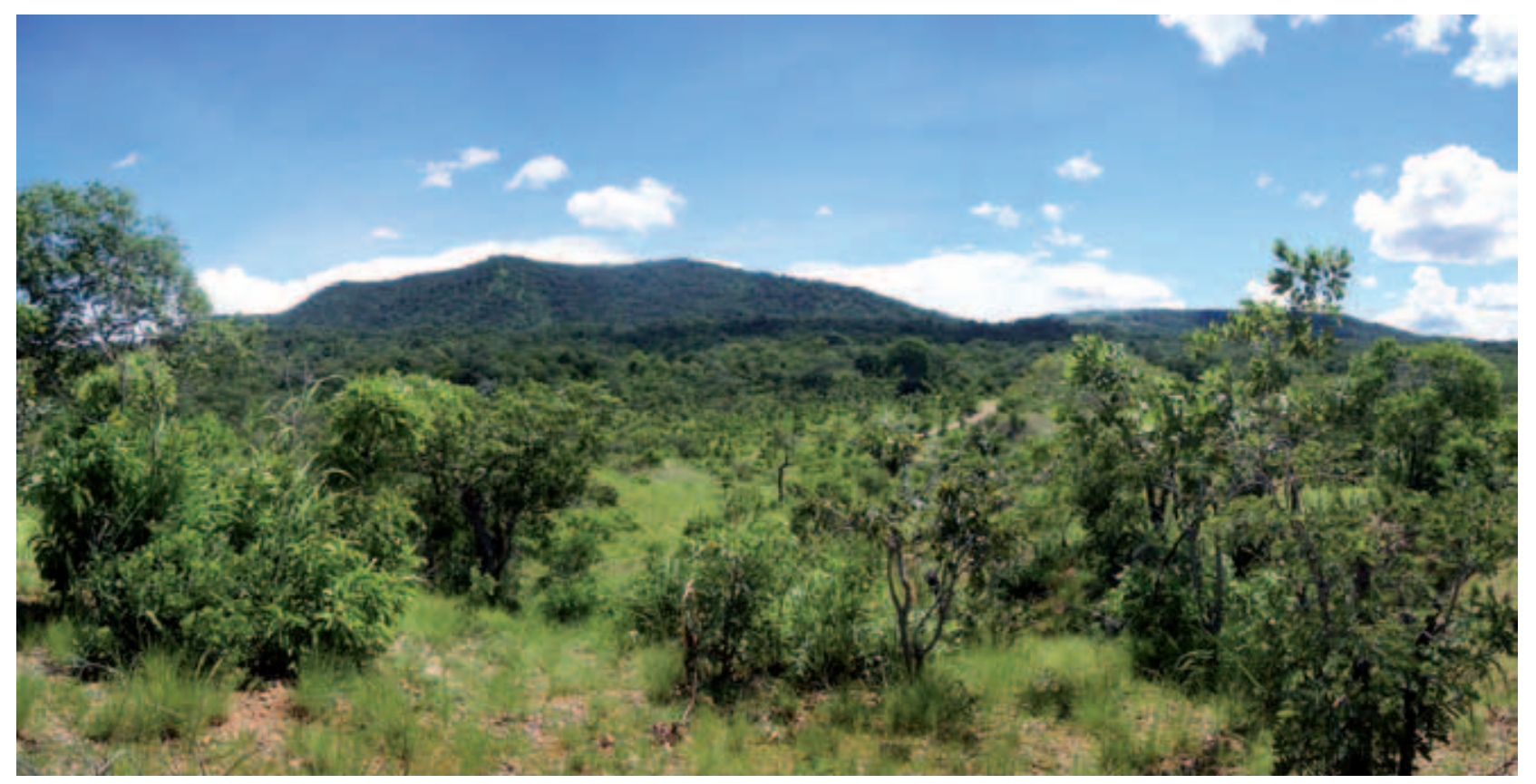

Fig. 2: Overview of the study site | Vue d'ensemble du terrain d'étude | Überblick des Untersuchungsgebiets

\section{STUdy Site}

The study site (Fig. 1 and 2) is located in the northern part of Malawi, about $10 \mathrm{~km}$ south of the city of Karonga (Karonga District). It has a surface area of $25 \mathrm{~km}^{2}$ and covers parts of the territories of the villages of Malema and Merere and as parts of the protected area Ulamwe hill. Its highest peak reaches $908 \mathrm{~m}$ above sea level and the lake level of Lake Malawi is situated at an altitude of $500 \mathrm{~m}$ a.s.1.

According to BRECKLE (1999), the area belongs to the zonobiome of savannas, deciduous forests and grasslands. The climate is characterised by a rainy season from mid - November to April followed by a dry season (Fig. 3). According to data (1971 to 2000) from the nearby weather station "Karonga Aerodrome", the average annual precipitation was $620 \mathrm{~mm}$, with lowest monthly precipitation of $0 \mathrm{~mm}$ (November) and highest precipitation of $540 \mathrm{~mm}$ (March). Mean lowest daily temperature was $17.2{ }^{\circ} \mathrm{C}$ (July), highest temperature was $32.9^{\circ} \mathrm{C}$ (November).

There are different types of soil found in the region. In general, the soils of the lake basin in lower altitudes consist of calcimorphic alluvial deposits (AGNEW \& STUBBS 1972). Reaching towards the inner countryside, precambric basement rocks form hills and mountains mainly of granite, quartz and mica schist which provide shallow horizons of lithosol. Ulamwe hill is such a structure of basement rock. There is another plateau of mica schist towards the lake shore before the area slopes and passes over to the lakeshore plain. In between those structures a plateau of calcimorphic alluvial deposits remains. This soil has a shallow fertile horizon and therefore is entirely used as arable land.

The zonal natural vegetation of most parts of Malawi is formed by Miombo woodland (COLE 1986). White (1983) distinguishes between two types of miombo woodland: a humid and a dry one. In the study site miombo woodland dominates in the protected area on the lithosol of Ulamwe Hill. On the more profound sandy soils of the region sloping towards Lake Malawi, there is a pattern of farmland and woodlands, thickets, scrubs and parklands which form small island-like thickets between the cultivated fields.

Termite mounds are found throughout the region. The activity of termites and other organisms alter the soils and, subsequently, also the vegetation structure (BACHELIER 1978). Bushfires occur frequently, even in the protected area. They are set and controlled by the residents in order to facilitate the hunting of small mammals, improve the fertility of the soil and to keep the area "tidy".

In the investigated villages, the main ethnic groups are Tumbuka and Ngonde. Most people live from agriculture or breeding of cattle and pigs. Most important crops are maize,

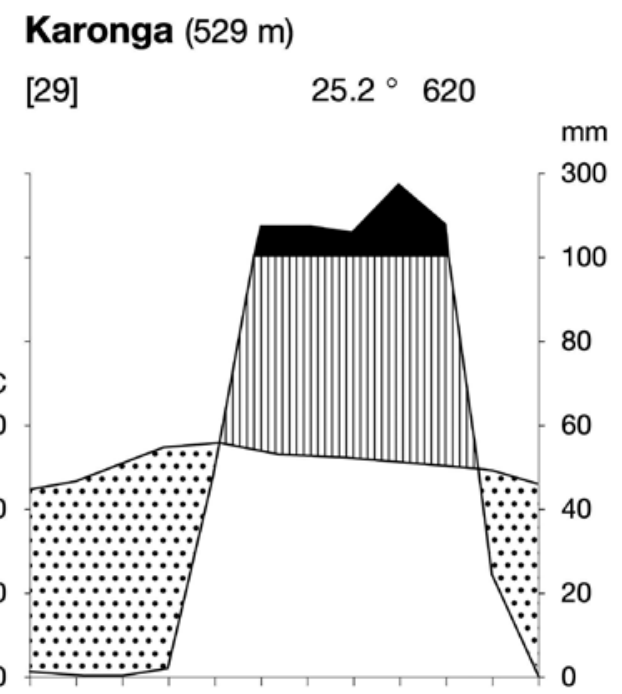

Fig. 3: Climate diagram of Karonga | Diagramme climatique de Karonga | Klimadiagramm von Karonga 
cassava, cotton, borassus palm and sesame. Wild plants are collected for many purposes: as fuel, for the construction of buildings and furniture, as alimentation and spices and for medicinal application.

\section{Methods}

The aim of the study was a first assessment of the impact of harvesting of wild plants on the vegetation composition and structure. Therefore, the landscape was classified in three areas for comparison. These zones are:

- Protected area at the slopes of Ulamwe hill (Zone 1)

- Transition zone bordering on the protected area (Zone 2)

- Area near villages (Zone 3; favoured for wild plant collection)

The vegetation was analysed in 10 relevés per defined area. The relevés consist of plots sized $30 \mathrm{~m}$ x $30 \mathrm{~m}$ each. The plots were selected according to their homogeneity and apparent soil features.

Due to the common occurrence of termite-mounds, they were included in the study and analysed in 10 plots adapted to the size of the termite-mound.

The coverage of the tree and shrub layer was recorded according to BRAUN-BLANQUET (1951). The tree layer was defined as the layer of woody species reaching above $5 \mathrm{~m}$ in height, the shrub layer as reaching from $1-5 \mathrm{~m}$.
For identification, "Trees of Southern Africa (COATES-PALGRAVE 2002), the "Field Guide to the Trees and Shrubs of the Miombo Woodlands" (SMith \& Allen 2004) and the Flora Zambesiaca (Kew Royal Botanic Gardens 2004) were used. Voucher specimens were collected from species which could not be clearly identified.. They were determined and verified by staff members of the National Herbarium and Botanic Gardens of Malawi in Zomba and later on submitted to the Herbarium Senckenbergianum Frankfurt/M. (FR). Nomenclature follows African Plant Database (http://www.ville-ge.ch/musinfo/bd/cjb/africa/recherche.php).

\section{Results}

In total, 80 woody species were identified in the relevés, the tree layer consisting of 32 species and the shrub layer being composed of 77 species. According to the species composition, the main vegetation type of the study site has to be classified as dry miombo woodland including elements of "rupicolous bushland and thicket" and "termite mound thicket” (WhiTe 1983).

Table 1 shows the floristic composition of the miombo woodland. Figures 4, 5 and 6 highlight the differences between protected area (Fig. 4), transition zone (Fig. 5) and the surrounding of the villages (Fig. 6). Two variants of the miombo woodland were identified. The variant represented by relevés 11 to 30 of Table 1 . is differentiated by a high number of differential species showing more or less high presence (Margaritaria discoidea, Rytigynia adenodonta

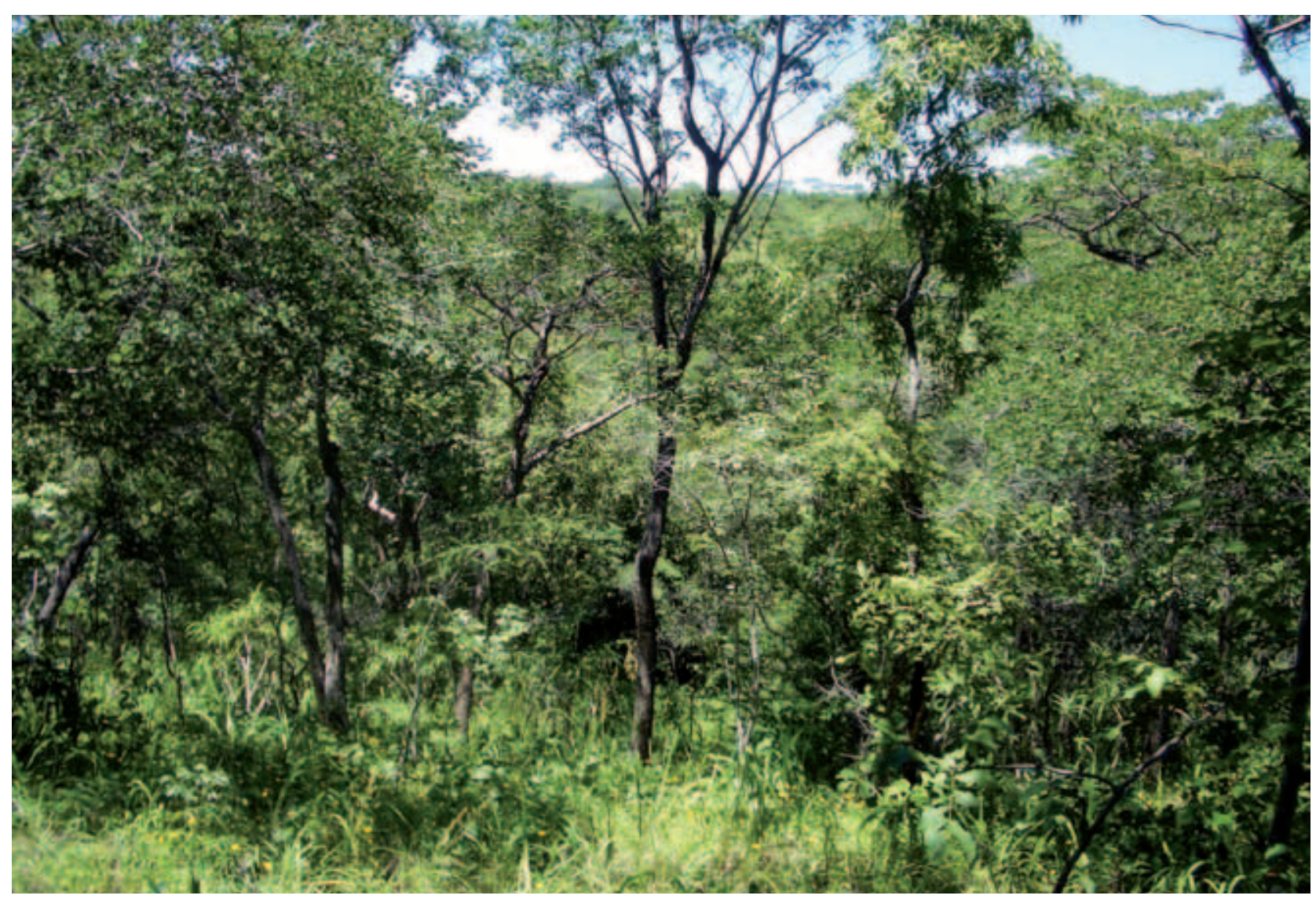

Fig. 4: Miombo woodland in the protected area (Zone 1) | Miombo woodland dans la zone protégée (Zone 1) $\mid$ Miombo woodland im Schutzgebiet (Zone 1) 
Table 1: Floristic composition of the woody vegetation in the zones 1-3 $(\mathrm{c}=$ constancy)

Tableau 1: Composition floristique de la végétation ligneuse dans les zones 1-3 $(\mathrm{c}=$ constance)

Tabelle 1: Floristische Zusammensetzung der Gehölzvegetation in den Zonen 1-3 (c = Stetigkeit)

\begin{tabular}{|c|c|c|c|c|c|c|c|c|c|c|c|c|c|c|c|c|c|c|c|c|c|c|c|c|c|c|c|c|c|c|}
\hline No. of relevé & 1 & 2 & 3 & 4 & 5 & 6 & 7 & 8 & 9 & 10 & 11 & 12 & 13 & 14 & 15 & 16 & 17 & 18 & 19 & 20 & 21 & 22 & 23 & 24 & 25 & 26 & 27 & 28 & 29 & 30 \\
\hline Area & 3 & 1 & 1 & 1 & 2 & 2 & 2 & 2 & 2 & 1 & 2 & 1 & 1 & 1 & 1 & 1 & 1 & 2 & 2 & 2 & 2 & 3 & 3 & 3 & 3 & 3 & 3 & 3 & 3 & 3 \\
\hline Tree cover (\%) & 3 & 50 & 50 & 50 & 25 & 35 & 10 & 20 & 25 & 30 & 15 & 35 & 55 & 60 & 30 & 50 & 55 & 30 & 20 & 25 & 30 & 10 & 1 & 1 & 3 & 3 & 5 & - & - & 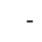 \\
\hline Shrub cover (\%) & 45 & 40 & 40 & 30 & 35 & 30 & 35 & 40 & 40 & 40 & 30 & 45 & 50 & 70 & 55 & 40 & 50 & 30 & 55 & 40 & 40 & 80 & 70 & 60 & 60 & 55 & 65 & 60 & 50 & 60 \\
\hline No. of species & 16 & 20 & 17 & 18 & 18 & 20 & 19 & 15 & 13 & 13 & 12 & 25 & 19 & 22 & 22 & 23 & 24 & 17 & 29 & 23 & 11 & 38 & 17 & 18 & 16 & 21 & 21 & 21 & 20 & 17 \\
\hline Exposition & W & $\mathbf{N}$ & W & $\mathbf{E}$ & SE & $\mathrm{S}$ & - & $\mathbf{E}$ & $\mathbf{S}$ & $\mathbf{N}$ & NE & $\mathbf{E}$ & $\mathbf{E}$ & $\mathbf{E}$ & $\mathbf{S}$ & SE & SE & $\mathbf{E}$ & $\mathbf{E}$ & $\mathbf{E}$ & $\mathbf{E}$ & $\mathbf{N}$ & $\mathbf{N}$ & (N) & $\mathrm{S}$ & $\mathbf{S}$ & $(\mathrm{N})$ & $\mathbf{N}$ & $\mathbf{N}$ & 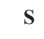 \\
\hline Slope & 15 & 30 & 25 & 15 & 20 & 10 & - & 10 & 15 & 25 & 10 & 20 & 25 & 20 & 30 & 20 & 30 & 10 & 10 & 5 & 15 & 20 & 10 & 3 & 20 & 10 & 3 & 15 & 10 & 15 \\
\hline
\end{tabular}

Tree layer $(>5 \mathrm{~m})$

Differential species

Commiphora mossambicensis

Combretum apiculatum

Strychnos madagascariensis

Diplorhynchus condylocarpon

Steady companions

Julbernardia globiflora

Lannea discolour

Brachystegia allenii

Pseudolachnostylis maprouneifolia

Terminalia stenostachya

Other companions

Acacia nigrescens

Euphorbia matabelensis

Commiphora mollis

Sterculia africana

Diospyros kirkii

Combretum adenogonium

Olax dissitiflora

Tarenna microphylla

Coptosperma neurophyllum

Hymenodictyon parvifolium

Manilkara obovata

Terminalia kaiseriana

Canthium oligocarpum

Acacia sp.

Azanza garckeana

Bauhinia petersiana

Shrub layer (1-5 m)

Differential species

Combretum adenogonium

Terminalia kaiseriana

Xerophyta splendens

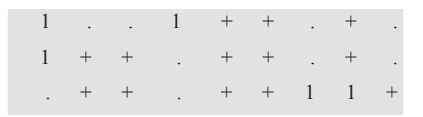

Margaritaria discoidea (Baill.)

G.L.Webster var. discoidea

Rytigynia adenodonta var. reticu-

lata

Maerua parvifolia

Olax dissitiflora

Ormocarpum kirkii

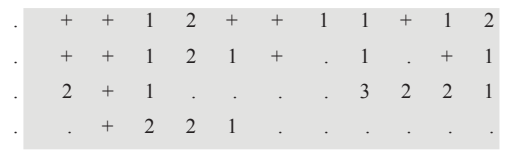

II

II

$\underline{\text { Steady companions }}$

Commiphora mossambicensis Lannea discolour

Combretum apiculatum

Bauhinia petersiana

Diplorhynchus condylocarpon

Euphorbia matabelensis

Julbernardia globiflora

Canthium glaucum frangula

Terminalia stenostachya

Strychnos madagascariensis
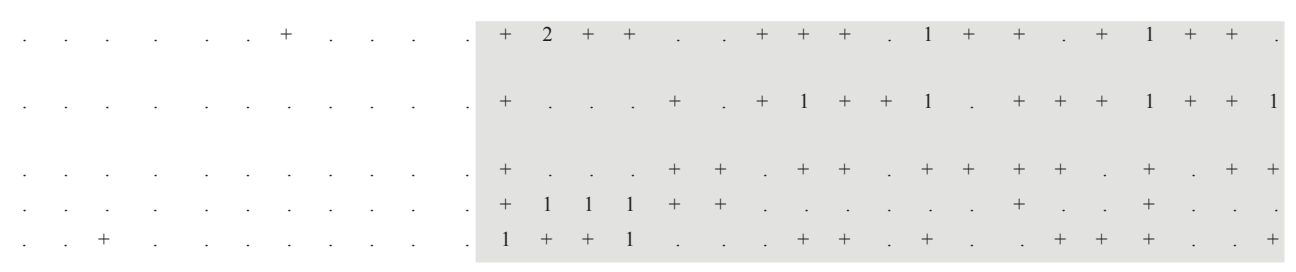


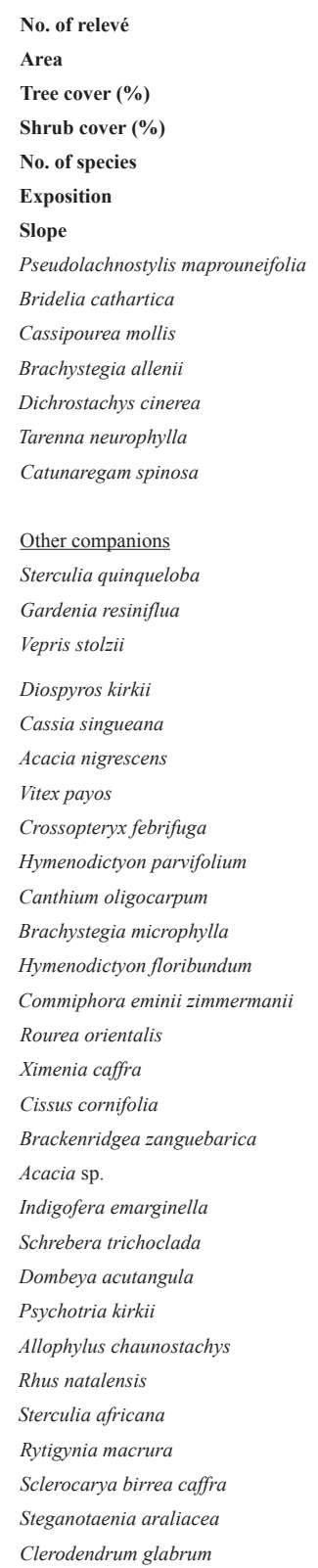

$\begin{array}{llllllllllllllllllllllllllllll}1 & 2 & 3 & 4 & 5 & 6 & 7 & 8 & 9 & 10 & 11 & 12 & 13 & 14 & 15 & 16 & 17 & 18 & 19 & 20 & 21 & 22 & 23 & 24 & 25 & 26 & 27 & 28 & 29 & 30\end{array}$ $\begin{array}{llllllllllllllllllllllllllllll}3 & 1 & 1 & 1 & 2 & 2 & 2 & 2 & 2 & 1 & 2 & 1 & 1 & 1 & 1 & 1 & 1 & 2 & 2 & 2 & 2 & 3 & 3 & 3 & 3 & 3 & 3 & 3 & 3 & 3\end{array}$

$\begin{array}{lllllllllllllllllllllllllllllll}3 & 50 & 50 & 50 & 25 & 35 & 10 & 20 & 25 & 30 & 15 & 35 & 55 & 60 & 30 & 50 & 55 & 30 & 20 & 25 & 30 & 10 & 1 & 1 & 3 & 3 & 5 & - & - & -\end{array}$

$\begin{array}{lllllllllllllllllllllllllllllll}45 & 40 & 40 & 30 & 35 & 30 & 35 & 40 & 40 & 40 & 30 & 45 & 50 & 70 & 55 & 40 & 50 & 30 & 55 & 40 & 40 & 80 & 70 & 60 & 60 & 55 & 65 & 60 & 50 & 60\end{array}$ $\begin{array}{lllllllllllllllllllllllllllllll}16 & 20 & 17 & 18 & 18 & 20 & 19 & 15 & 13 & 13 & 12 & 25 & 19 & 22 & 22 & 23 & 24 & 17 & 29 & 23 & 11 & 38 & 17 & 18 & 16 & 21 & 21 & 21 & 20 & 17\end{array}$ $\begin{array}{llllllllllllllllllllllllllllll}\text { W } & \text { N } & \text { W } & \text { E } & \text { SE } & \text { S } & - & \text { E } & \text { S } & \text { N } & \text { NE } & \text { E } & \text { E } & \text { E } & \text { S } & \text { SE } & \text { SE } & \text { E } & \text { E } & \text { E } & \text { E } & \text { N } & \text { N } & \text { (N) } & \text { S } & \text { S } & \text { (N) } & \text { N } & \text { N } & \text { S }\end{array}$ $\begin{array}{llllllllllllllllllllllllllllll}15 & 30 & 25 & 15 & 20 & 10 & - & 10 & 15 & 25 & 10 & 20 & 25 & 20 & 30 & 20 & 30 & 10 & 10 & 5 & 15 & 20 & 10 & 3 & 20 & 10 & 3 & 15 & 10 & 15\end{array}$

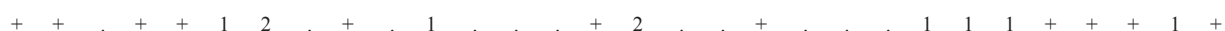
$+.++\quad+1$.

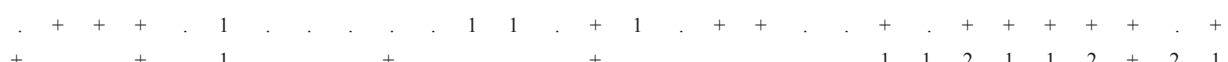

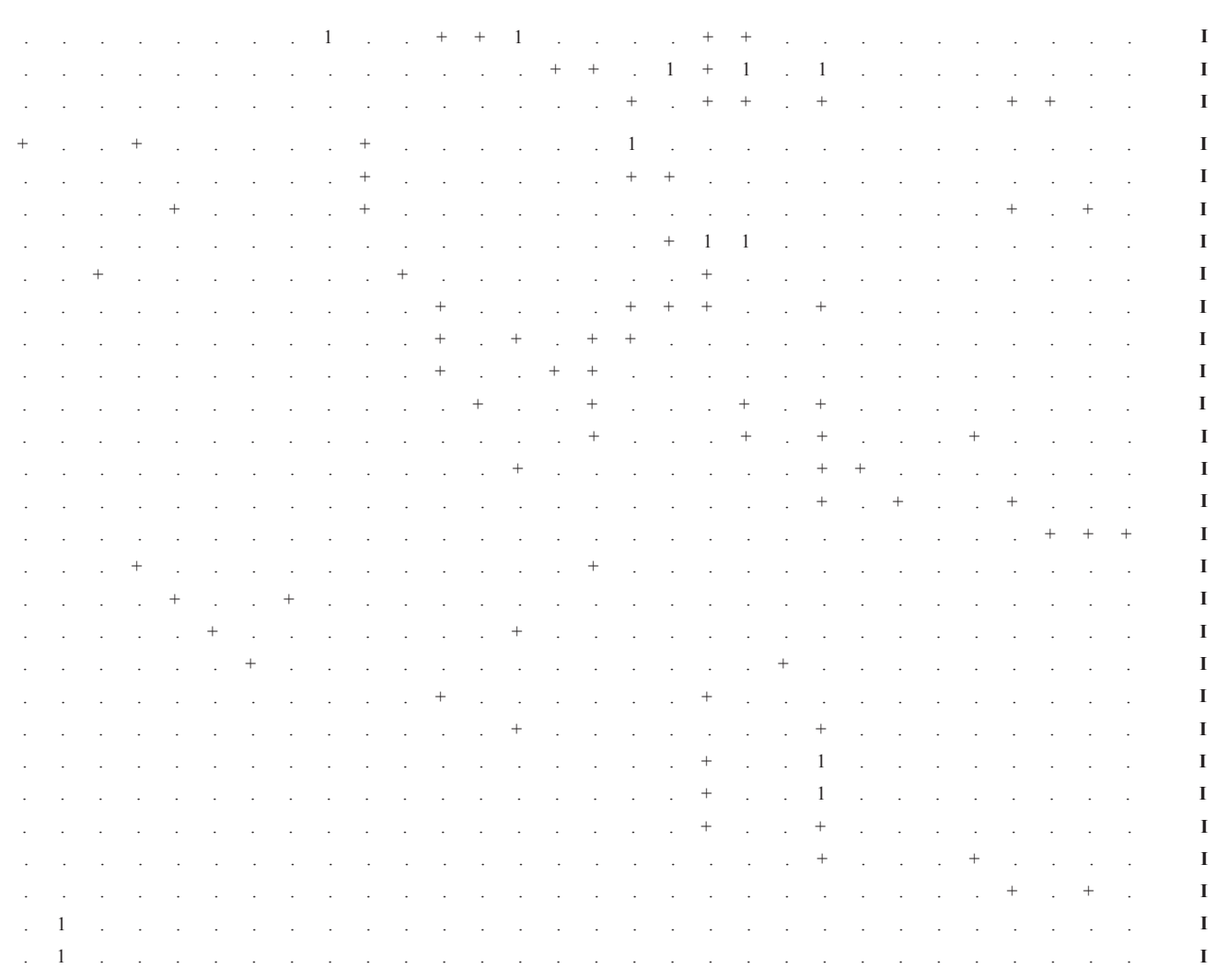

Additonally with + in Relevé No. 4: Acacia gerrardii; Bridelia cathartica; 2: Cussonia arborea; 6: Flacourtia indica; 13 : Dichrostachys cinerea, Grewia stolzii; 15: Maerua triphylla; 17: Dalbergia nitidula, Rytigynia adenodonta var. reticulate; 18: Holarrhena pubescens; 19: Kirkia acuminata, Phytolacca dodecandra; 20: Azanza garckeana, Rytigynia monantha; 22: Afzelia quanzensis, Commiphora africana, Eminia antennulifera, Ficus natalensis; 24: Boscia mossambicensis.

var. reticulata, Maerua parvifolia, Olax dissitiflora, Ormocarpum kirkii). This variant consists of a subtype with a well developed tree layer and one, more or less, treeless subtype. In the tree layer, additional differential species exist: Commiphora mossambicensis, Combretum apiculatum, Strychnos madagascariensis and Diplorhynchus condylocarpon. The second variant is mainly negatively differentiated, but some weak differential species exist (Combretum adenogonium, Terminalia kaiseriana and Xerophyta splendens). One of the relevés shown in Table 1 (No. 10) has an intermediate position between these two variants.

The vegetation on termite mounds (Table 2, Fig. 7) forms dense thickets. The species prevailing on the mounds differ from those characteristic for the other vegetation types. Five species are restricted to termite mounds: Boscia angustifolia var. corymbosa, Cadaba kirkii, Grewia bicolor, Maerua angolensis and Rhynchosia caribaea. A variant is characterised by the occurrence of Combretum apiculatum, Commiphora puguensis and Sterculia africana in the tree layer.

In all the three zones, the shrub cover is of almost $50 \%$ with the highest figures in Zones 1 and 3. The tree cover decreases from Zone 1 (47 \%) towards Zone 3 (3\%). In average, 20 woody species are found per plot which are mostly shrubs (average 18 species). On termite mounds, tree cover is even higher (70\%), but the average number of species is lower (9). The average number of trees and their maximum height decreases from Zone 1 towards Zone 3 (from 8 species to 1 species). The average maximum height of woody 


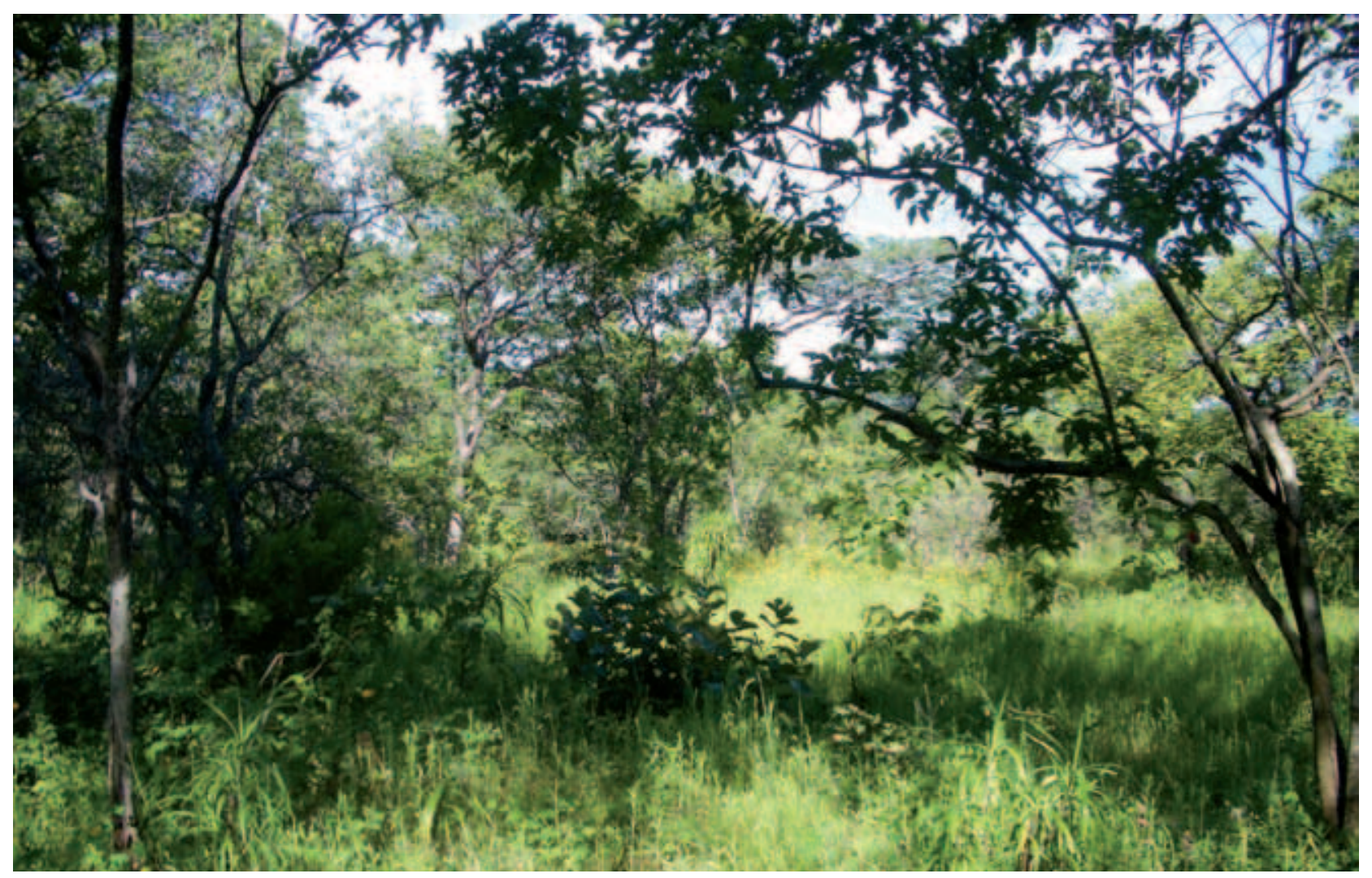

Fig. 5: Miombo woodland in the transition zone (Zone 2) $\mid$ Miombo woodland dans la zone de transition (Zone 2) $\mid$ Miombo woodland im Übergangsgebiet (Zone 2)

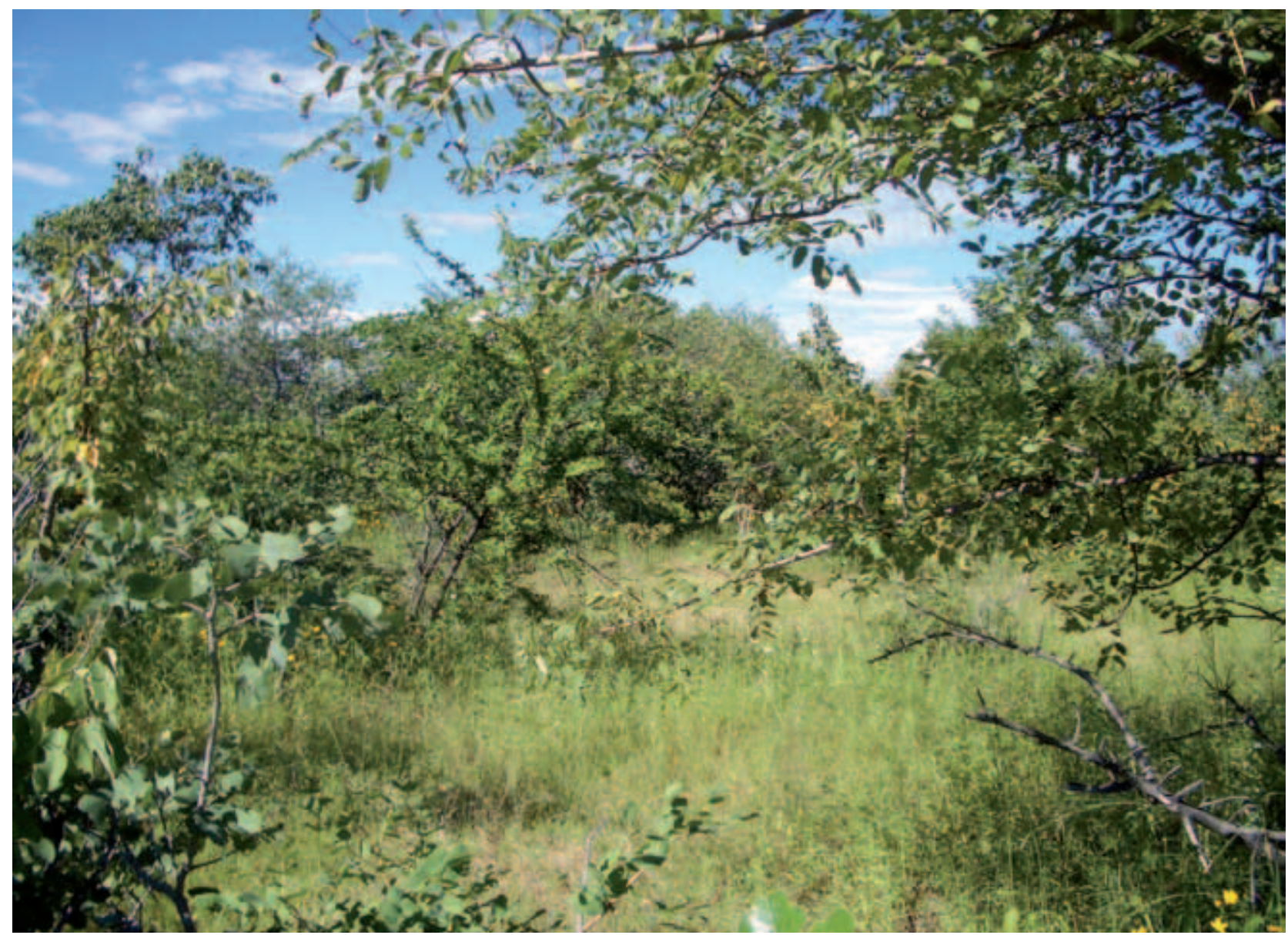

Fig. 6: Miombo woodland in the area near the villages (Zone 3) | Miombo woodland dans la zone près des villages (Zone 3) | Miombo woodland im siedlungsnahen Gebiet (Zone 3) 


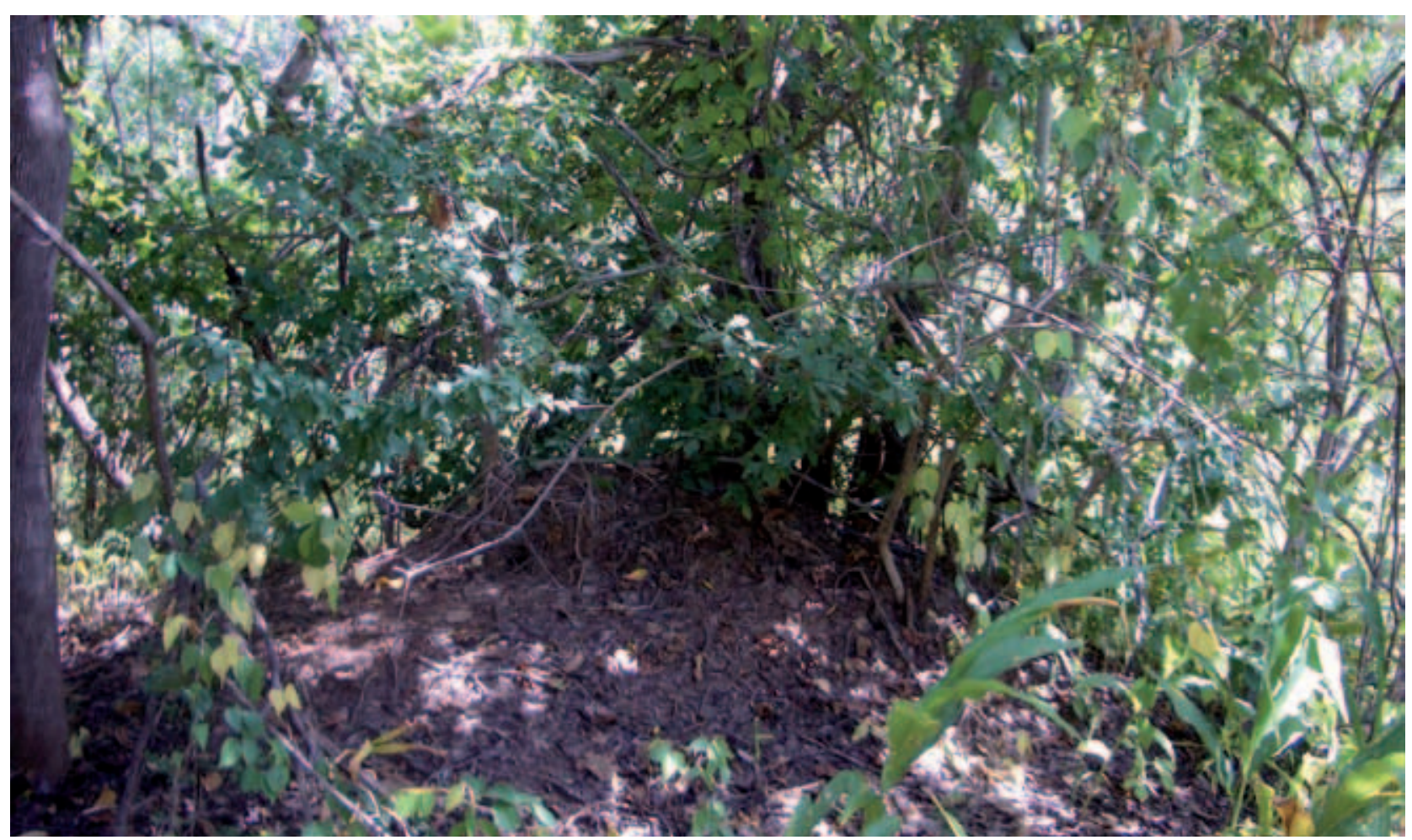

Fig. 7: Vegetation of a typical termite mound | Végétation sur une termitière typique | Vegetation auf einem typischen Termitenhügel

plants is $8.2 \mathrm{~m}$, with $7.4 \mathrm{~m}$ on termite mounds. The highest trees found in the plots reach $12 \mathrm{~m}$ and $13 \mathrm{~m}$ on the termite mounds.

The species composition is similar in the area near the villages compared to the protected area. Yet a difference can be found in the tree layer of the area favoured for harvesting of wild plants. Near the villages, trees rarely reach heights of over $5 \mathrm{~m}$ in contrast to the protected area where they often reach $10 \mathrm{~m}$ (compare Figures 4, 5 and 6).

\section{Discussion}

Geographically and thus floristically, Malawi represents a transition region between Eastern, Southern and Central Africa. Miombo woodland occurs throughout this region but shows differences in its floristic composition. In all variants of miombo woodland the dominating species belong to the genera Julbernardia, Isoberlinia or Brachystegia. Termite mounds occur all over the Sudano-Zambezian savanna belt, but local variation of their floristic composition is not yet very well studied.

The floristic composition of miombo woodland in the study site is more related to the Tanzanian types of miombo (BACKÉUs et al. 2006, BoAler 1966, BurTt 1942) than to the Zambian miombo woodland (CHIDUMAYO 1987, TRAPNELL 1959). This can be explained by the local geomorphology and soils (see below). In addition, the East African Rift escarpment separates the north Malawian woodland from the south western (Zambian) woodlands. The fact that our study area in the map of White (1983) is assigned to the wet miombo woodland while we stated dry miombo woodland is not really contradictory but might be a matter of scale.

Apart from anthropogenic influences which comprise most of the frequent bushfires, soil conditions are of importance for the structure and species composition of the vegetation. Miombo woodland species in general prefer shallow soils rich in minerals, a condition which exists more or less equally in our study area. Bushfires however, occur most frequently in Zone 2 which might explain the lower cover of the shrub layer observed in this zone. In the study site a variant including Combretum adenogonium is found. C. adenogonium, which WhITE (1983) characterises as belonging to the general type of the undifferentiated miombo woodland, was observed in our case only in a particular subtype. This might be explained by the observations of BOALER (1966), who considered C. adenogonium as a typical species of disturbed habitats. This is not contradictory to our findings where $C$. adenogonium mainly occurs on soils with high moisture content, because higher moisture means higher productivity and thus a higher degree of disturbance by grazing animals.

Some relevés on termite mounds show a remarkable tree layer in combination with a higher number of species. As in general only dead termite mounds are colonised by plant species, this indicates that the mounds were abandoned by the termites a long time ago. Three of the five species restricted to termite mounds belong to the family Capparaceae. These species prefer base-saturated soils as found on termite mounds (FANSHAWE 1986). The species are characteristic for these specific soil conditions and apparently those species, if found in other relevés, could indicate the former occurrence of a termite mound already eroded or another type of soil with similar conditions as provided by the activity of termites. These results underline the importance of termites and termite mounds for the vegetation composition and plant diversity of the region.

The diversity of the miombo woodland in the study area shows no clear differences in regard to the use of wild 
Table 2: Floristic composition of the woody vegetation on termite mounds $(c=$ constancy $)$

Tableau 2: Composition floristique de la végétation ligneuse sur les termitières $(c=$ constance $)$

Tabelle 2: Floristische Zusammensetzung der Gehölzvegetation auf Termitenhügeln $(c=$ Stetigkeit $)$

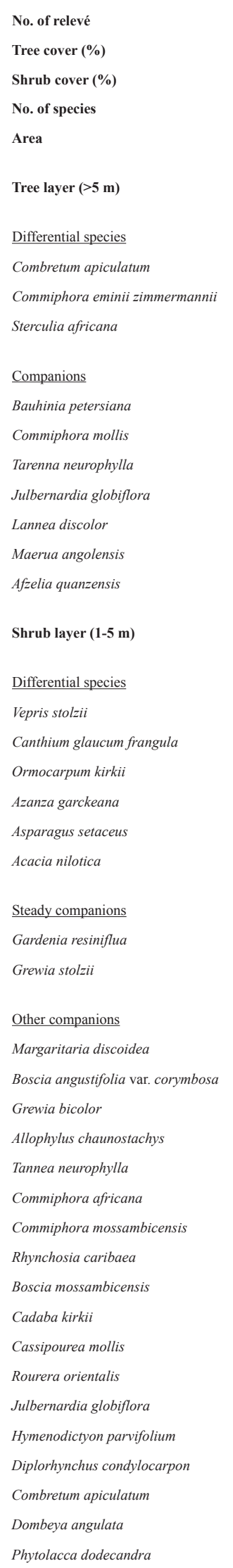

plants. However, the tree layer is strongly affected by human activities such as bushfires and browsing. Many woody species are adapted to bushfires and damage caused by browsing animals by the ability to produce new coppice shoots. This can be observed throughout the study area. Many plants can survive after felling by this adaptation as well. Thus, the diversity is currently not influenced by harvesting of wild plants. It is more influenced by the predominating soils and the occurrence of bushfires. In contrast the physiognomic aspect of the vegetation is altered and an influence can be perceived.

These study results are in concordance with those of other authors stating that the collection of wild plants does not necessarily result in a degradation of the vegetation (АВвот \& Homewood 1999, Banda et al. 2006, Dewees 1989, FoLEY 2001). However, succession in miombo woodland is not fully understood (TRAPNELL 1959) and a long-term impact cannot be out ruled. BANDA et al. (2006), though on a larger scale, provide results similar to this study and even show that a strict protection can result in a decrease of species. It would be important would be to quantify harvesting intensities and the valuation of woodlands in economical terms (DEwEEs et al. 2010) for developing possibilities of a sustainable management, including the provision of an income and poverty reduction for the local populace.

\section{ACKNOWLEDGMENTS}

We are especially grateful to our field assistant Oswell Mwantende who proved to be an experienced and dedicated hobby botanist. Special thanks as well to Friedemann Schrenk, Prof. of Palaeoanthropology at the University of Frankfurt and the Senckenberg Research Institute, who facilitated our study in the area of Karonga, Dick Byer for a language check and Edwin Kathumba of the National Herbarium and Botanic Gardens of Malawi in Zomba for helping with plant identification.

\section{REFERENCES}

Аввот J I \& Homewood K (1999): A history of change: Causes of miombo woodland decline in Malawi. - J. Appl. Ecol. 36: 422-433.

Agnew S \& Stubbs M (1972): Malawi in Maps. - University of London Press.

BACHELIER G (1978): La faune des sols: son écologie et son action. - O.R.S.T.O.M., Paris.

Backéus I, Pettersson B, Strömquist L \& Ruffo C (2006): Tree communities and structural dynamics in the miombo (Brachystegia-Julbernardia) woodland, Tanzania. Forest Ecol. Managem. 230: 171-178.

BANDA T, SCHWARTZ M W \& CARO T (2006): Woody vegetation structure and composition along a protection gradient in a miombo ecosystem of western Tanzania. - Forest Ecol. Management 230: 179-185.

BOALER SB (1966): Ecology of a Miombo Site, Lupa North Forest Reserve, Tanzania: II. Plant Communities and Seasonal Variation in the Vegetation. - J. Ecol. 54: 465-479. 
BRECKLE S-W (1999): Walter's Vegetation of the Earth. Springer Verlag, Berlin.

BuNDSCHUH TV (2008): Einfluss der Nutzungsintensität auf die Häufigkeit von Medizinalpflanzen in der Umgebung von Malema. - Diplomarbeit am Fachbereich Biologie der J.W. Goethe-Universität Frankfurt am Main.

BURTT BD (1942): Some East African vegetation communities. - J. Ecol. 30: 65-146.

Campbell B (1996): The Miombo in Transition: Woodlands and Welfare in Africa. - Bogor, Indonesien: Center for International Forestry Research.

Chidumayo EN (1987): Woodland Structure, Destruction and Conservation in the Copperbelt Area of Zambia. - Biol. Conservation 40: 89-100.

Coates-Palgrave M (2002): Keith Coates-Palgrave Trees of Southern Africa. - Struik Publishers, Cape Town.

Cole MM (1963): Vegetation and Geomorphology in Northern Rhodesia: An Aspect of the Distribution of the Savanna of Central Africa. - Geogr. J. 129: 290-305.

DEWEES PA (1989): The woodfuel crisis reconsidered: observations on the dynamics of abundance and scarcity. World Development 8: 1159-1172.

Dewees Pa, Campbell BM, Katerere Y, Sitoe A, CunNINGHAM AB \& Wunder S (2010): Managing the Miombo Woodlands of Southern Africa: Policies, Incentives and Options for the Rural Poor. - J. Nat. Resources Policy Res. 1: 57-73.

FANSHAWE DB (1968): The vegetation of Zambian termitaria. - Kirkia: Botany of Zimbabwe 6: 169-179.

Foley G (2001): Sustainable Woodfuel Supplies from the Dry Tropical Woodlands. - Energy Sector Management Assistance Programme (ESMAP). Washington: World Bank.

Halle B \& Burgess J (2006): Country Environmental Profile for Malawi. - Commision of the European Communities. Les Isnes (Belgien): AGRIFOR Consult.
KAUNDA YL (2007): Rapid appraisal report on the use of wild plant species by ethnic groups in the Malema nature trail project catchment area. - Unpubl. (CMCK), Karonga.

Macmillan Malawi LTD. (2005): Senior Secondary Atlas. - Macmillan Publishers Limited, Blantyre

Royal Botanic Gardens, Kew (2004): Flora Zambesiaca. - Accessed in August 2008 through http://apps.kew.org/ efloras/search.do.

Schrenk F, Bromage TG, Betzler CG, Ring U \& JuwaYEYI YM (1993): Oldest Homo and Pliocene biogeography of the Malawi Rift. - Nature 365: 833-836.

Smith P \& Allen Q (2004): Field Guide to the Trees and Shrubs of the Miombo Woodlands. - Kew: Royal Botanic Gardens.

TRAPNELL CG (1959): Ecological Results of Woodland and Burning Experiments in Northern Rhodesia. The Journal of Ecology 47: 129-168.

WhiTe F (1983): The vegetation of Africa. - UNESCO, Paris.

\section{AdDREsSES OF THE AUTHORS}

Tina Vanadis Bundschuh Rüdiger Wittig

Karen Hahn

Institute of Ecology, Evolution and Diversity

Goethe-Universität

Siesmayerstraße 70

D-60323 Frankfurt am Main

Germany

eMail: tina.bundschuh@gmx.net eMail:r.wittig@bio.uni-frankfurt.de eMail: karen.hahn@bio.uni-frankfurt.de 


\section{APPENDIX}

A I: List of woody plants species and their local names (in alphabetical order of the scientific names).

Liste des espèces ligneuses et leurs noms locaux (en ordre alphabétique des noms scientifiques).

Liste der Gehölzarten und ihrer Lokalnamen (in alphabetischer Reihenfolge der wissenschaftlichen Namen).

\begin{tabular}{|c|c|c|c|}
\hline $\begin{array}{l}\text { Accepted scientific name } \\
\text { (African Plant Data Base) }\end{array}$ & Plant family & $\begin{array}{l}\text { Local name (Chi- } \\
\text { tumbuka/ Chink- } \\
\text { honde) }\end{array}$ & Synonyms \\
\hline Acacia gerrardii Benth. & Fabaceae & & \\
\hline Acacia nigrescens Oliv. & Fabaceae & Mkuntu & \\
\hline Acacia nilotica (L.) Willd. ex Del. & Fabaceae & Chibiriri & \\
\hline Afzelia quanzensis Welw. & Fabaceae & Kamilang'onga & \\
\hline Allophylus chaunostachys Gilg & Sapindaceae & Nyatatu & \\
\hline Asparagus setaceus (Kunth) Jessop & Asparagaceae & Mkhorankhanga & \\
\hline Azanza garckeana (F. Hoffm.) Exell \& Hillc. & Malvaceae & Mtowo & \\
\hline Bauhinia petersiana Bolle & Fabaceae & Mpapa & \\
\hline Boscia angustifolia A.Rich. var. corymbosa (Gilg) DeWolf & Capparaceae & Luvwi & \\
\hline Boscia mossambicensis Klotzsch & Capparaceae & Luvwi & \\
\hline Brachystegia allenii Hutch. \& Burtt Davy & Fabaceae & Nguti & \\
\hline Brachystegia microphylla Harms & Fabaceae & Msalasala & $\begin{array}{l}\text { Brachystegia tamarindoides ssp. } \\
\text { microphylla (Harms) Chikuni }\end{array}$ \\
\hline Brackenridgea zanguebarica Oliv. & Ochnaceae & & \\
\hline Bridelia cathartica G.Bertol. & Euphorbiaceae & Mguzabango & \\
\hline Cadaba kirkii Oliv. & Capparaceae & Mbozga & \\
\hline Canthium glaucum ssp. frangula (S.Moore) Bridson & Rubiaceae & Kamyong' onyo & \\
\hline Canthium oligocarpum Hiern & Rubiaceae & & \\
\hline Cassia singueana Delile (accepted in FTA) & Fabaceae & Kamemena & Senna singueana (Delile) Lock \\
\hline Cassipourea mollis (R.E.Fr.) Alston & Rhizophoraceae & Kafulankhwale & \\
\hline Catunaregam spinosa (Thunb.) Tirveng. & Rubiaceae & Mvunganjati & $\begin{array}{l}\text { Catunaregam obovata (Hochst.) } \\
\text { A.E. Gonç. }\end{array}$ \\
\hline Cissus cornifolia (Baker) Planch. & Vitaceae & Mlewe ("male") & \\
\hline Clerodendrum glabrum E. Mey. & Verbenaceae & Kawingawazimu & \\
\hline Combretum adenogonium Steud. ex A.Rich. & Combretaceae & Kansewe & Combretum fragrans F. Hoffm. \\
\hline Combretum apiculatum Sond. & Combretaceae & Mlama & \\
\hline Commiphora africana (A. Rich.) Engl. & Burseraceae & Nyatatu & \\
\hline Commiphora eminii subsp. zimmermannii (Engl.) J.B.Gillett & Burseraceae & Chitonto ("green") & Commiphora puguensis Engl. \\
\hline Commiphora mollis (Oliv.) Engl. & Burseraceae & Chitonto & \\
\hline Commiphora mossambicensis (Oliv.) Engl. & Burseraceae & Chitonto & \\
\hline Crossopteryx febrifuga (Afzel. ex G.Don) Benth. & Rubiaceae & Chiwaja chikhowo & \\
\hline Cussonia arborea Hochst. ex A.Rich. & Araliaceae & Chimpombwe & \\
\hline Dalbergia nitidula Baker & Fabaceae & Luwewa & \\
\hline Dichrostachys cinerea (L.) Wight \& Arn. & Fabaceae & Mphangala & \\
\hline Diospyros kirkii Hiern & Ebenaceae & Chigulya & \\
\hline Diplorhynchus condylocarpon (Müll. Arg.) Pichon & Apocynaceae & Mnthalembe & \\
\hline Dombeya acutangula Cav. & Sterculiaceae & & Dombeya cincinnata K. Schum. \\
\hline Eminia antennulifera (Baker) Taub. & Fabaceae & & \\
\hline Euphorbia matabelensis Pax & Euphorbiaceae & Wulimbo & \\
\hline Ficus natalensis Hochst. & Moraceae & Mvumu & \\
\hline Flacourtia indica (Burm.f.) Merr. & Flacourtiaceae & Ndawi & \\
\hline Gardenia resiniflua Hiern & Rubiaceae & Nyatatu & \\
\hline Grewia bicolor Juss. & Tiliaceae & Lusako & \\
\hline Grewia stolzii Ulbr. & Tiliaceae & & \\
\hline Holarrhena pubescens (Buch.-Ham.) Wall. ex G.Don & Apocynaceae & Njenje & \\
\hline Hymenodictyon floribundum (Hochst. \& Steud.) Robbr. & Rubiaceae & Chitechitechi & \\
\hline
\end{tabular}




\begin{tabular}{|c|c|c|c|}
\hline Approved scientific name & Plant family & Local name & Synonyms \\
\hline Hymenodictyon parvifolium Oliv. & Rubiaceae & & \\
\hline Indigofera emarginella Steud. ex A.Rich. & Fabaceae & Mwafongo & \\
\hline Julbernardia globiflora (Benth.) Troupin & Fabaceae & Kamphoni & \\
\hline Kigelia africana (Lam.) Benth. & Bignoniaceae & Mfungwe & \\
\hline Kirkia acuminata Oliv. & Simaroubaceae & Mzumbazumba & \\
\hline Lannea discolor (Sond.) Engl. & Anacardiaceae & Kaumbweumbwe & \\
\hline Maerua angolensis DC. & Capparaceae & & \\
\hline Maerua parvifolia $\mathrm{Pax}$ & Capparaceae & Luvwi & \\
\hline Maerua triphylla A.Rich. & Capparaceae & & Maerua cafra (DC.) Pax \\
\hline Manilkara obovata (Sabine \& G.Don) J.H.Hemsl. & Sapotaceae & & \\
\hline Margaritaria discoidea (Baill.) G.L. Webster & Euphorbiaceae & & \\
\hline Olax dissitiflora Oliv. & Olacaceae & Foka & \\
\hline Ormocarpum kirkii S.Moore & Fabaceae & Mbankho & \\
\hline Phytolacca dodecandra L'Hér. & Phytolaccaceae & & \\
\hline Pseudolachnostylis maprouneifolia Pax & Euphorbiaceae & Msolo & \\
\hline Psychotria kirkii Hiern & Rubiaceae & & \\
\hline Rhus natalensis Bernh. ex C.Krauss & Anacardiaceae & Nyatatu & \\
\hline Rhynchosia caribaea (Jacq.) DC. & Fabaceae & & \\
\hline Rourea orientalis Baill. & Connaraceae & Mwawani & $\begin{array}{l}\text { Byrsocarpus orientalis (Baill.) } \\
\text { Bak. }\end{array}$ \\
\hline Rytigynia adenodonta var. reticulata (Robyns) Verdc. & Rubiaceae & Mpokuso & \\
\hline Rytigynia bugoyensis (K.Krause) Verdc. & Rubiaceae & & \\
\hline Rytigynia macrura Verdc. & Rubiaceae & & \\
\hline Rytigynia monantha (K.Schum.) Robyns & Rubiaceae & Mpokuso & \\
\hline Rytigynia reticulata Robyns & Rubiaceae & Mpokuso & $\begin{array}{l}\text { Rytigynia adenodonta var. reti- } \\
\text { culata (Robyns) Verdc. }\end{array}$ \\
\hline Schrebera trichoclada Welw. & Anacardiaceae & Mpioka & \\
\hline Sclerocarya birrea subsp. caffra (Sond.) Kokwaro & Anacardiaceae & Msere & Sclerocarya caffra Sond. \\
\hline Steganotaenia araliacea Hochst. & Apiaceae & Mnyongoloko & \\
\hline Sterculia africana (Lour.) Fiori & Sterculiaceae & Muyamba & \\
\hline Sterculia quinqueloba (Garcke) K.Schum. & Sterculiaceae & Mosha & \\
\hline Strychnos madagascariensis Poir. & Loganiaceae & Kamira walumba & \\
\hline Tarenna neurophylla (S.Moore) Bremek. & Rubiaceae & & $\begin{array}{l}\text { Coptosperma neurophyllum } \\
\text { (S. Moore) Degreef }\end{array}$ \\
\hline Terminalia kaiseriana F.Hoffm. & Combretaceae & Mpululu & \\
\hline Terminalia stenostachya Engl. \& Diels & Combretaceae & Mpokwa & \\
\hline Vepris stolzii 1.Verd. & Rutaceae & Foka & \\
\hline Vitex payos (Lour.) Merr. & Lamiaceae & Mfuru & \\
\hline Xerophyta splendens (Rendle) N.L.Menezes & Velloziaceae & Chisuche & \\
\hline Ximenia caffra Sond. & Olacaceae & Mlewe (edible) & \\
\hline
\end{tabular}


A II: List of the plant families and the associated species. | Liste des familles des plantes et des espèces correspondantes. | Liste der Pflanzenfamilien und ihnen zugehöriger Spezies

Anacardiaceae

Lannea discolor

Rhus natalensis

Schrebera trichoclada

Sclerocarya birrea caffra

\section{Apiaceae}

Steganotaenia araliacea

\section{Apocynaceae}

Diplorhynchus condylocarpon

Holarrhena pubescens

Araliaceae

Cussonia arborea

Asparagaceae

Asparagus setaceus

Bignoniaceae

Kigelia africana

\section{Burseraceae}

Commiphora africana

Commiphora mollis

Commiphora mossambicensis

Commiphora puguensis

\section{Capparaceae}

Boscia angustifolia

Boscia mossambicensis

Cadaba kirkii

Maerua angolensis

Maerua cafra

Maerua parvifolia

Combretaceae

Combretum apiculatum

Combretum adenogonium

Terminalia kaiseriana

Terminalia stenostachya

Connaraceae

Byrsocarpus orientalis

Ebenaceae

Diospyros kirkii

Euphorbiaceae

Bridelia cathartica

Euphorbia matabelensis

Margaritaria discoidea

Pseudolachnostylis maprouneifolia $\underline{\text { Fabaceae - Caesalpinioideae }}$

Bauhinia petersiana

Brachystegia allenii

Brachystegia tamarindoides

ssp. microphylla

Julbernardia globiflora

Senna singueana

Fabaceae - Mimosoideae

Acacia gerrardii

Acacia nigrescens

Acacia nilotica

Afzelia quanzensis

Dichrostachys cinerea

Fabaceae - Papilionoideae

Eminia antennulifera

Indigofera emarginella

Ormocarpum kirkii

Rhynchosia caribaea

Dalbergia nitidula

Flacourtiaceae

Flacourtia indica

Lamiaceae

Vitex payos

Loganiaceae

Strychnos madagascariensis

Malvaceae

Azanza garckeana

Moraceae

Ficus natalensis

Ochnaceae

Brackenridgea zanguebarica

Olacaceae

Olax dissitiflora

Ximenia caffra

Phytolaccaceae

Phytolacca dodecandra

Rhizophoraceae

Cassipourea mollis
Rubiaceae

Canthium glaucum frangula

Canthium oligocarpum

Catunaregam obovata

Coptosperma neurophyllum

Crossopteryx febrifuga

Gardenia resiniflua

Hymenodictyon floribundum

Hymenodictyon parvifolium

Psychotria kirkii

Rytigynia adenodonta var. reticulata

Rytigynia bugoyensis

Rytigynia macrura

Rytigynia monantha

Rutaceae

Vepris stolzii

Sapindaceae

Allophylus chaunostachys

$\underline{\text { Sapotaceae }}$

Manilkara obovata

$\underline{\text { Simaroubaceae }}$

Kirkia acuminata

$\underline{\text { Sterculiaceae }}$

Dombeya cincinnata

Sterculia africana

Sterculia quinqueloba

Tiliaceae

Grewia bicolor

Grewia stolzii

Velloziaceae

Xerophyta splendens

Verbenaceae

Clerodendrum glabrum

Vitaceae

Cissus cornifolia 